\title{
Bovine abortion by a vaccine strain of Bacillus anthracis
}

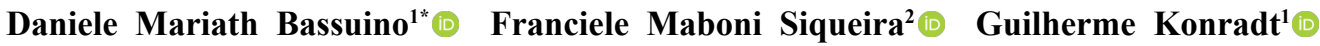 \\ Andréia Vielmo ${ }^{1}$ (i) Verônica Machado Rolim ${ }^{1}$ (i) Maiara Aline Gonçalves ${ }^{1}$ (iD \\ Samuel Paulo Cibulski ${ }^{3}$ (i) Gustavo Snel $^{4}$ (i) Fabiana Quoos Mayer ${ }^{5}$ (i) \\ Agueda Castagna de $\operatorname{Vargas}^{6}$ (D) David Driemeier ${ }^{1}$ (i) Saulo Petinatti Pavarini ${ }^{1}$ (I)
}

${ }^{1}$ Departamento de Patologia Veterinária, Setor de Patologia Veterinária, Universidade Federal do Rio Grande do Sul (UFRGS), 91540-000, Porto Alegre, RS, Brasil. E-mail: daniele.mariath@yahoo.com.br. *Corresponding author.

${ }^{2}$ Laboratório de Bacteriologia Veterinária, Universidade Federal do Rio Grande do Sul (UFRGS), Porto Alegre, RS, Brasil.

${ }^{3}$ Laboratório de Virologia Veterinária, Universidade Federal do Rio Grande do Sul (UFRGS), Porto Alegre, RS, Brasil.

${ }^{4}$ Universidade Federal do Rio Grande do Sul (UFRGS), Porto Alegre, RS, Brasil.

${ }^{5}$ Laboratório de Biologia Molecular, Instituto de Pesquisas Veterinárias Desidério Finamor (IPVDF), Fundação Estadual de Pesquisa Agropecuária, Eldorado do Sul, RS, Brasil.

${ }^{6}$ Laboratório de Bacteriologia, Departamento de Medicina Veterinária Preventiva, Universidade Federal de Santa Maria (UFSM), Santa Maria, RS, Brasil.

ABSTRACT: This paper reports the abortion of a male Aberdeen Angus bovine by a vaccine strain of Bacillus anthracis, describing the pathological and microbiological findings and the genome sequence. Necropsy findings included multifocal areas of hemorrhage in different organs. Histologically, various organs showed hemorrhage, fibrin exudation, necrosis associated with countless bacillary bacterial clumps and severe neutrophilic inflammatory infiltrate. In the microbiological examination, numerous rough, nonhemolytic, gray and dry colonies with irregular edges were isolated from liver, lung and abomasum content samples. Gram staining revealed square-ended Gram-positive rods arranged in chains. B. anthracis identification was confirmed by detection of the molecular chromosomal marker Ba813. The genomes from the isolated B. anthracis (named SPV842_15) and from the isolated vaccinal strain (Brazilian vaccinal strain), which was recovered from a commercial vaccine used in the pregnant cow, were sequenced. Genomic comparisons displayed a high level of nucleotide identity in the comparisons between B. anthracis SPV842_15 and the B. anthracis Brazilian vaccinal strain (98,2\%). Furthermore, in both strains, only the plasmid pX01 sequence was detected. Although, vaccination against anthrax is characterized by an elevated protective profile and very low residual virulence, immunization with Sterne strains can cause abortion in cattle, presumably by the plasmid pX01 toxins in rare or special situations. Key words: anthrax, cattle, fetal loss, infectious diseases.

Aborto bovino por uma cepa vacinal de Bacillus anthracis

RESUMO: Este trabalho relata um aborto de um bovino, macho, Aberdeen Angus, por uma cepa vacinal de Bacillus anthracis, descreve os achados patológicos, microbiológicos e o sequenciamento do genoma. Os achados de necropsia incluíram áreas multifocais de hemorragias em diferentes órgãos. Histologicamente, órgãos afetados apresentaram hemorragia, exsudação de fibrina, necrose associada a miríades bacterianas bacilares e intenso infiltrado inflamatório neutrofilico. No exame microbiológico, foram isoladas numerosas colônias rugosas, não hemoliticas, cinzas e secas, com bordas irregulares a partir de amostras de fígado, pulmão e conteúdo do abomaso. A coloração de Gram revelou bastonetes Gram-positivos dispostos em cadeias. A identificação do B. anthracis foi confirmada pela detecção do marcador cromossômico molecular Ba813. Os genomas do isolado B. anthracis (SPV842 15) e do isolado vacinal (cepa vacinal brasileira), recuperado de uma vacina comercial utilizada na vaca prenhe, foram sequenciados. Comparações genômicas mostraram um elevado nível de identidade de nucleotideos entre B. anthracis SPV842 15 e cepa vacinal brasileira (98,2\%). Além disso, em ambas as estirpes foi detectada apenas a sequência do plasmideo pX01. Embora a vacinação contra o antraz seja caracterizada por um perfil protetor elevado e uma virulência residual muito baixa, a imunização com estirpes de Sterne pode causar aborto em bovinos, presumivelmente pelas toxinas do plasmideo pX01 em situações raras ou especificas.

Palavras-chave: antraz, bovino, perdas fetais, doenças infecciosas.

Bacillus anthracis is a gram-positive encapsulated bacterium that causes a serious infection in humans, domestic animals and wild animals (MARKEY et al., 2013). This bacterium contains two plasmids: the pX01 plasmid carries the genes for three major toxins: lethal factor (LF), protective antigen (PA), and edema factor (EF) (WELKOS \& FRIEDLANDER, 1988). The 
pX02 plasmid carries the genes cap (B, C, A) and $d e p$, which are required for the biosynthesis of an antiphagocytic poly-d-glutamic acid capsule (WELKOS et al., 1986) that provides resistance to phagocytosis by macrophages (GREEN et al., 1985; MAKINO et al., 1989). The pathogenicity of $B$. anthracis decreases markedly when either plasmid is removed (WELKOS et al., 1986).

The Sterne nonvirulent spore vaccine, which is recommended for immunization against anthrax, is characterized by an elevated protective capacity and very low residual virulence. The lack of pXO2 plasmid in the Sterne strain is responsible for its attenuation. Here, we described bovine abortion by a pathogenic vaccinal strain of $B$. anthracis, with insights into the bacterial genome sequence and pathological findings.

A bovine aborted fetus, Aberdeen Angus breed, measuring $81 \mathrm{~cm}$ from the neck to the tail (corresponding to eight months of gestation) was referred for necropsy examination. The organs were examined macroscopically, processed for routine histological examination, and stained with hematoxylin and eosin (HE) and Gram (modified Brown-Hopps) stains. Lung and liver fragments and abomasal content were collected and plated onto $5 \%$ sheep blood agar and MacConkey agar and incubated at $37^{\circ} \mathrm{C}$ for 48 hours.

Bacterial DNA was extracted using the DNeasy Blood \& Tissue Kit (Qiagen, Hilden, Germany). A PCR assay for the marker Ba813 R1/ $\mathrm{R} 2$, which is a specific chromosomal marker of $B$. anthracis, and the genes for the capsule biosynthesis cap (B, C, A) 17/20 and cap (C) 57/58 were performed according to FASANELLA et al. (2001). The oligonucleotide specificity control was based on one reaction with Bacillus cereus ATCC 14579 DNA as a template. In this reaction, no amplification of the marker Ba813 in the B. cereus DNA was detected.

Vaccine spores, which were originally derived from the Sterne strain (same vaccine used for cow immunization), were cultivated in 5\% sheep blood agar. Genomic DNA, for high-throughput sequencing, from the Brazilian vaccinal strain and from B. anthracis SPV842_15 were extracted by lysis with cetyltrimethylammonium bromide (CTAB) following the addition of phenol:chloroform. The DNA was sequenced on an Illumina MiSeq system. The complete genome and pX01 plasmid sequences of B. anthracis strain SPV842_15 have the accession numbers CP019588.1 and CP019589.1, respectively. The $B$. anthracis Brazilian vaccinal strain genome (as the shotgun genome) has the accession
MVOA00000000 and its pX01 plasmid under number CM007716.1 (SIQUEIRA et al., 2017).

Comparative analysis and alignment were performed using the progressive Mauve Algorithm (DARLING et al. 2004). Furthermore, the Genometo-Genome Distance Calculator tool, GGDC (http:// ggdc.dsmz.de/distcalc2.php), was used to calculate the DNA-to-DNA difference (MEIER-KOLTHOFF et al. 2013), which provides the in silico DNA-DNA hybridization (DDH) distance between genomes with confidence interval estimation. DDH analysis was performed with the following $B$. anthracis genomes: SPV842_15 strain (CP019588.1), Ames strain (NC_003997), and Sterne strain (NC_005945).

The fetus was from a beef cattle farm. The cow had been vaccinated for anthrax 40 days before the abortion episode. The cow died hours after abortion; however, it was not necropsied. At fetal necropsy, multiple hemorrhages in the form of bruises and suffusion in intercostal muscles were observed accompanied by a mild accumulation of lemon-yellow free fluid in the chest cavity. The lungs were diffusely reddened and collapsed, with a density higher than that of the fixative solution. A large amount of bloody fluid was reported inside the pericardial sac. Extensive hemorrhagic areas were observed in the epicardial surface of the heart (Figure 1A), extending to the endocardium. The spleen showed a slight increase in size. Upon microscopic examination of the lung, marked multifocal hemorrhage areas of fibrin exudation in the alveoli and bronchioles were observed, along with neutrophilic infiltrate and numerous bacterial rods measuring 1.2-10 $\mu \mathrm{m} \times 0.5-2.5 \mu \mathrm{m}$, arranged individually or forming small chains. The heart had marked multifocal hemorrhage associated with bacterial clumps with foci of necrosis, accumulation of neutrophils and cellular debris (Figure 1B). In the kidney, there was marked hemorrhage, with multifocal bacterial clumps inside the vessels and glomeruli (Figure 1C), visualized as Gram-positive rods inside glomeruli, tubules and renal interstitium. The liver had mild multifocal thrombosis, multiple bacterial cells within the vessels (Figure 1D) and random multifocal necrosis of the hepatocytes. The spleen showed hemorrhage, marked multifocal coagulation necrosis and numerous bacterial clumps. The brain showed marked multifocal congestion, and perivascular hemorrhage and fibrin thrombi containing bacillary bacterial structures were rarely observed.

In the bacteriological examination, numerous rough, nonhemolytic, gray and dry colonies with irregular edges (ground-glass appearance) were 


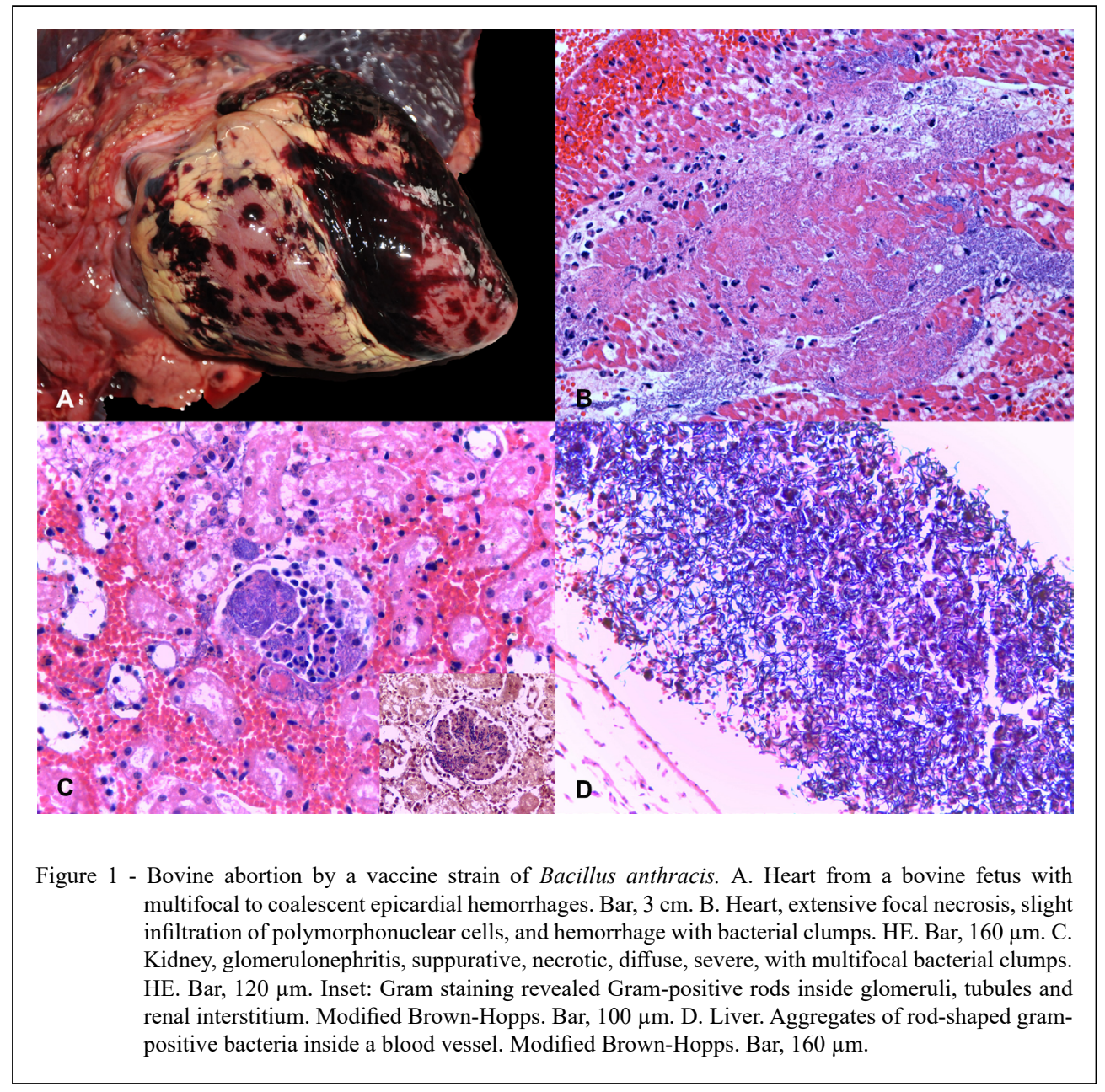

isolated from liver, lung and abomasum content samples. Gram staining revealed square-ended Grampositive rods arranged in chains, some of which contained central elliptical spores. Based on the isolate characteristics that were compatible with the agent of anthrax (MARKEY et al., 2013), we performed gamma phage lysis (BROWN \& CHERRY, 1955), where the strain was susceptible, resulting in bacterial lysis. The strain was named B. anthracis SPV842_15.

The genes for capsule biosynthesis were not detected in the SPV842 15 strain by cap (B, C, A) $17 / 20$ and cap (C) $5 \overline{7} / 58$ PCRs. Therefore, we hypothesize that the vaccine nonencapsulated attenuated bacteria may have a threshold pathogenic response following immunological and physiological responses from the cow after vaccination. To confirm this hypothesis, we performed whole genome sequencing of the isolated B. anthracis SPV842 15 and the Brazilian vaccinal strain. In both strains, only the plasmid pX01 sequence was detected and completely assembled.

The Mauve alignment among genomes demonstrated a high level of nucleotide identity in the comparisons between $B$. anthracis SPV842 15 and $B$. anthracis Brazilian vaccinal whole genomes $(98.2 \%)$, in addition to more similar identity levels between B. anthracis SPV842 15 and the reference B. anthracis Sterne genome (NC_005945) (99.98\%), then in the comparisons between $B$. anthracis SPV842_15 and the reference pathogenic $B$. anthracis Ames strain (NC_003997) (99.90\%). B. anthracis genomes have a highly nucleotide conservative profile, with the Ames genome and Sterne genome having $99.90 \%$ identity. According to PILO \& FREY (2011), due to the long dormant spore periods, $B$. anthracis evolves very slowly. Consequently, $B$. anthracis is genetically homogeneous. Therefore, the identification and discrimination of strains are

Ciência Rural, v.50, n.12, 2020. 
allowed by genome comparison approaches (KEIM et al., 2009; PILO \& FREY, 2011).

To improve information about the percentages of genomic resemblance, we performed an in silico DDH analysis by the GGDC method between the genome SPV842_15 versus reference genomes, Ames strain and Sterne strain. The GGDC method locally aligned two genomes using BLAST and produced a set of high-scoring segment pairs (HSPs). The GGDC results indicated that $B$. anthracis SPV842 15 has a lower distance from the Sterne strain (0.0001) than the Ames strain (0.0003), which represents a higher DDH estimate; consequently, the higher similarity between SPV842_15 and Sterne strains illustrates the genomic relationship of $B$. anthracis SPV842_15 with vaccinal clones. Unfortunately, we were unable to perform this genome comparison with the Brazilian vaccinal strain because this genome was assembled only as a draft genome.

The complete sequences of the $\mathrm{pX} 01$ plasmid from each $B$. anthracis genome were assembled, and the Mauve alignment showed complete identity (Figure 2). Interestingly, no sequence matching with pX02 plasmids was detected by Blast analysis in the genome of the strain SPV842_15. This finding supports the previously negative PCR assays with the primers cap (B,C,A) $17 / 20$ and cap (C) 57/58. Accordingly, we can ensure the absence of the $\mathrm{pX} 02$ plasmid in the pathogenic B. anthracis SPV842_15 strain and the presence of the pX01 plasmid in this strain, with high identity to the $\mathrm{pX} 01$ plasmid from the $B$. anthracis Brazilian vaccinal strain. Associating this detection to the high identity of the genomes (SPV842_15 strain versus Brazilian vaccinal strain), which was described above, we are able to affirm that strain SPV842_15 is a non wild pathogenic $B$. anthracis, and then abortion was caused by the vaccinal strain.

Anthrax bacilli as causative of abortion have been previously reported only by GIBBONS \& HUSSAINI (1974). Immunization against $B$. anthracis in cattle is performed with live $B$. anthracis spores (Sterne strain). This design prevents the onset of an acute infection as spores are slowly released in small amounts. However, little is known about the specific immunity induced by vaccination in ruminants. In summary, the released spores germinate, and the antigenic components that assemble the toxin are produced (carried out by the pXO1 plasmid): lethal factor, edema factor, and, especially, the protective antigen, against which the immune response is directed. The immune system then activates phagocytic macrophages and eliminates vegetative forms (WELKOS et al., 2001). The phagocytosis activation process depends on the host's immune capacity, and immunosuppressive factors may act by inhibiting this process. The health history of the cow, in this report, is unknown, so it is impossible to infer whether other immunosuppressive events were present in addition to physiological transient immunosuppression during pregnancy when the animal was vaccinated. Thus, the septicemic abortion in this case may have been an isolated event, not necessarily related only to a residual pathogenicity of

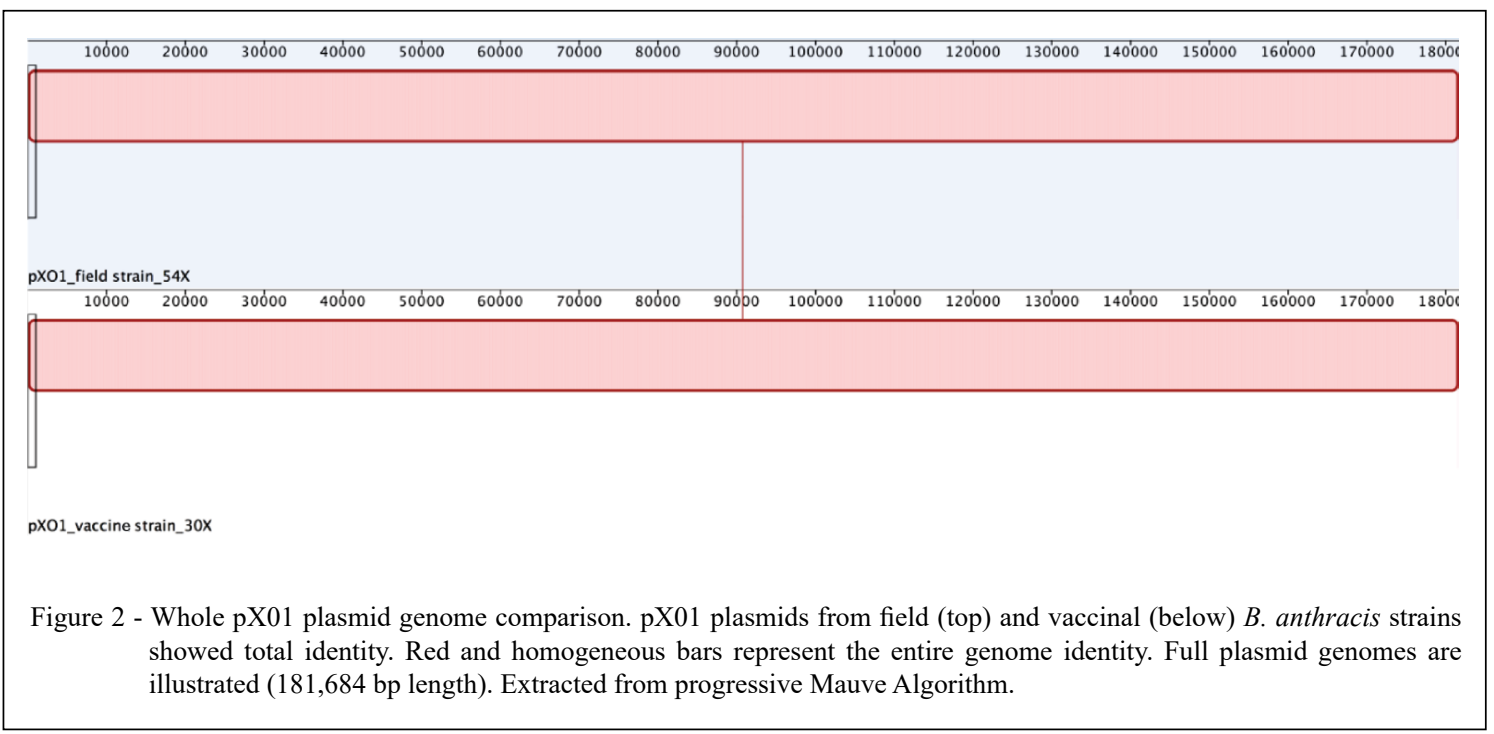

Ciência Rural, v.50, n.12, 2020. 
the vaccinal strain, since the vaccine is widely used for many years in pregnant cows.

Vaccination against anthrax is characterized by an elevated protective profile and very low residual virulence. However, it may cause abortion in cattle, presumably by the pX01 toxins in rare or special situations.

\section{ACKNOWLEDGEMENTS}

Authors are grateful to Conselho Nacional de Desenvolvimento Científico e Tecnológico (CNPq), and was financed in part by the Coordenação de Aperfeiçoamento de Pessoal de Nível Superior (CAPES), Brasil - Finance code 001.

\section{DECLARATION OF CONFLICT OF INTERESTS}

The authors declare no conflicts of interest. The founding sponsors had no role in the design of the study; in the collection, analyses, or interpretation of data; in the writing of the manuscript; or in the decision to publish the results.

\section{AUTHORS' CONTRIBUTIONS}

The authors contributed equally to the manuscript.

\section{REFERENCES}

BROWN, E. R.; CHERRY, W. B. Specific identification of Bacillus anthracis by means of a variant bacteriophage. The Journal of Infectious Diseases, v.96, p.34-39, 1955. Available from: <https:// www.jstor.org/stable/30092380?seq=1>. Accessed: Mar. 20, 2020. doi: 10.1093/infdis/96.1.34.

DARLING, A. C. et al. Mauve: Multiple alignment of conserved genomic sequence with rearrangements. Genome Research, v.14, p.1394-1403, 2004. Available from: <https://genome.cshlp.org/ content/14/7/1394.short>. Accessed: Mar. 18, 2020. doi: 10.1101/ gr.2289704.

FASANELLA, A. et al. Detection of anthrax vaccine virulence factors by polymerase chain reaction. Vaccine, v.19, p.4214-4218, 2001. Available from: <https://www.sciencedirect.com/science/ article/pii/S0264410X01001591>. Accessed: Mar. 15, 2020. doi: 10.1016/S0264-410X(01)00159-1.

GIBBONS, D. F., HUSSAINI, S. N. Isolation of Bacillus anthracis from an aborted bovine foetus. Nature, v.252, p.612, 1974. Available from: <https://www.nature.com/articles/252612a0>. Accessed: Feb. 20, 2020. doi: 10.1038/252612a0.

GREEN, B. D. et al. Demonstration of a capsule plasmid in Bacillus anthracis. Infection and Immunity, v.49, p.291-297,
1985. Available from: <https://www.ncbi.nlm.nih.gov/pmc/ articles/PMC262013/>. Accessed: Mar. 10, 2020. doi: 10.1128/ IAI.49.2.291-297.

KEIM, P. et al. The genome and variation of Bacilus anthracis. Molecular Aspects of Medicine, v.30, p.397-405, 2009. Available from: <https://www.sciencedirect.com/science/ article/pii/S0098299709000600>. Accessed: Feb. 10, 2020. doi: 10.1016/j.mam.2009.08.005.

MAKINO, S. et al. Molecular characterization and protein analysis of the cap region, which is essential for encapsulation in Bacillus anthracis. Journal of Bacteriology, v.171, p.722-30, 1989. Available from: <https://jb.asm.org/content/171/2/722. short>. Accessed: Mar. 08, 2020. doi: 10.1128/jb.171.2.722-730.

MARKEY, B. et al. Clinical Veterinary Microbiology. 2 ed. Philadelphia: Sauders Elsevier, 2013. 920p.

MEIER-KOLTHOFF, J. P. et al. Genome sequencebased species delimitation with confidence intervals and improved distance functions. BMC Bioinformatics, v.14, p.1-14, 2013. Available from: <https://link.springer.com/ article/10.1186/1471-2105-14-60>. Accessed: Jan. 20, 2020. doi: $10.1186 / 1471-2105-14-60$.

PILO, P.; FREY, J. Bacillus anthracis: Molecular taxonomy, population genetics, phylogeny and patho-evolution. Infection, Genetic and Evolution, v.11, p.1218-1224, 2011. Available from: <https://www.sciencedirect.com/science/article/pii/ S1567134811002012>. Accessed: Jan. 10, 2020. doi: 10.1016/j. meegid.2011.05.013.

SIQUEIRA, F. M. et al. Genome sequencing of two Bacillus anthracis strains: a virulent strain and a vaccinal strain. Brazilian Journal of Microbiology, v.49, n.1, p.18-19, 2017. Available from: <https://www.ncbi.nlm.nih.gov/pmc/articles/ PMC5790590/>. Accessed: Mar. 22, 2020. doi: 10.1016/j. bjm.2017.04.007.

WELKOS, S. L. et al. Differences in susceptibility of inbred mice to Bacillus anthracis. Infection and Immunity, v.51, p.795-800, 1986. Available from: <https://www.ncbi.nlm.nih. gov/pmc/articles/PMC260968/>. Accessed: Jan. 05, 2020. doi: 10.1128/iai.51.3.795-800.

WELKOS, S. L.; FRIEDLANDER, A. M. Pathogenesis and genetic control of resistance to the Sterne strain of Bacillus anthracis. Microbial Pathogenesis, v.4, p.53-69, 1988. Available from: $<$ https://www.sciencedirect.com/science/article/ abs/pii/0882401088900484>. Accessed: Nov. 10, 2019. doi: $10.1016 / 0882-4010(88) 90048-4$.

WELKOS, S. et al. The role of antibodies to Bacillus anthracis and anthrax toxin components in inhibiting the early stages of infection by anthrax spores. Microbiology, v.147, p.1677-1685, 2001. Available from: <https://www.microbiologyresearch.org/content/ journal/micro/10.1099/00221287-147-6-1677>. Accessed: Mar. 18, 2020. doi: 10.1099/00221287-147-6-1677. 